\title{
CORRIGENDUM
}

\section{Identification of mealybug pest species (Hemiptera: Pseudococcidae) in Egypt and France, using a DNA barcoding approach - CORRIGENDUM}

\author{
S. Abd-Rabou, H. Shalaby, J.-F. Germain, N. Ris, P. Kreiter \\ and T. Malausa
}

doi:10.1017/S0007485312000041, Published by Cambridge University Press, 24 February 2012.

The specimen \#1269 (as defined in Table S1), voucher \#1002170 (Table 2), from collection site F19 (Table 1), displaying haplotypes 28S-07 and LCO-18 (associated to Dysmicoccus brevipes), was erroneously added to the dataset as it was NOT collected in France or Egypt. It should be excluded from this study. As it was the only specimen identified as D. brevipes, no Dysmicoccus brevipes specimen was found in this survey.

\section{Reference}

Abd-Rabou, S., Shalaby, H., Germain, J.-F., Ris, N., Kreiter, P. and Malausa, T. Identification of mealybug pest species (Hemiptera:

Pseudococcidae) in Egypt and France, using a DNA barcoding approach. Bulletin of Entomological Research, Published by Cambridge University Press, 24 February 2012. doi:10.1017/S0007485312000041. 